\title{
SOCIAL RESPONSIBILITY FOR BANKING INSTITUTIONS
}

\author{
Anna BERÁNKOVÁ; Jana BLAŽKOVÁ; Jana GLÁSEROVÁ;. Milena OTAVOVÁ.
}

Mendel University in Brno, Faculty of Business and Economics, Brno, Czech Republic

\begin{abstract}
The paper is focused on the evaluation of the impacts of the implementation of Directive 2014/95 / EU in terms of the introduction of non-financial information into Czech accounting legislation, specifically the Accounting Act with effect from 2017. The subject of this research are financial institutions, specifically commercial banks based in the Czech Republic. Banks such as public interest entities must operate not only monitor and manage credit risk, which results from their active subject matter, but along with it the risk of longterm sustainability in a comprehensive and consistent. This requirement is fulfilled by the regular reporting of non-financial information by banks. Transparent disclosure of this information should help to eliminate banking risks and creating greater credibility, which is crucial for banks. Trendy sustainability should be fully consistent with the principles of business and commercial activities.

Purpose: The aim of the paper is to evaluate the benefits of the implementation of the Directive in the Accounting Act on the quantity and quality of reported non-financial information by banks operating in the Czech Republic. The paper evaluates and compares approaches to this fact not only for banks that have this obligation, but also for banks that do not have this obligation. There was also a comparison of the reporting rate of nonfinancial information by banks within the Visegrad countries.
\end{abstract}

Methodology: Based on Directive 2014/95 / EU and the EUKI 2020 database, key indicators in the area of non-financial reporting were identified, for which the level of their reporting by the monitored banks was subsequently monitored. It has established five basic areas, ie. The environment, social issues, employees, respect for human rights and the fight against corruption and bribery. Within individual areas, partial indicators were defined and subsequently monitored. The starting point was the content analysis of banks' annual reports. All banks in the Czech Republic (a total of 48 banks) were analyzed, which were then divided into three basic groupsThese are banks with an obligation to disclose nonfinancial information, banks that are defined as large entities and a group of other banks according to the Accounting Act. After the identification of defined areas and the content analysis of the annual reports, the quantity and quality of non-financial reporting for the monitored groups of banks were evaluated. These results were compared with data obtained from the EUKI database for banks in other V4 countries.

Findings: Significant differences were found between the reporting of non-financial information by banks with the obligation to report, when a growing trend can be noted in the quality and quantity of reported non-financial information. This cannot be confirmed for banks that do not have this obligation. It should be added that some smaller banks, despite their importance, still do not report non-financial information. It was also found that when reporting non-financial information by banks, there is no uniform form and content with regard to the choice of specific indicators. From the results of comparisons within other V4 countries, it was found that in comparison with the Czech Republic, non-financial information is reported in more detail in Poland and Slovakia, but less in detail in Hungary.

Keywords: non-financial information, non-financial reporting, directive 2014/95 / EU, banks, sustainability

https://doi.org/10.11118/978-80-7509-820-7-0144 


\section{Introduction}

In recent years, the importance of corporate social responsibility has been growing, which is not just a matter of the company's image, but is becoming part of business models. Thanks to this importance, a large company creates separate departments that deal with social responsibility and try to involve their employees in it. Directive 2014/95 / EU is focused on corporate social responsibility and financial institutions. According to this directive is the non-financial disclosure mandatory for public interest entities, which are also banking institutions. Banks through project financing and lending to have a big impact on today's society and therefore should be in the area to raise awareness.

The issue of social responsibility is much more common and debated in Western countries than in Central and Eastern Europe. In Western Europe, social responsibility is also more required of citizens and investors who decide to invest in banking institutions on the basis of non-financial information.

The aim of the paper is to evaluate the benefits of the implementation of the Directive in the Accounting Act on the quantity of reported non-financial information by banks operating in the Czech Republic. The article is focused on financial institutions, specifically on commercial banks and foreign branches of banks based in the Czech Republic.

\section{Literature review / Research Background}

„Our planet could be seen as our billion stars hotel; we are called to behave as properly and well-educated guests, and as responsible guests, we have to respect and care about our hotel and leave it in the best condition for future visitors. " (Bedenik a Barišić, p. 120)

Transition to economy with respect to environment can be realized in three stages: including the environmental costs of carbon into the prices paid by all sectors of economy, greater information duty about envrionmental issues and innovation facilitating carbon replacement (ECB, 2021).

Until 2017 non-financial information were disclosed voluntarily, but on January 1of this year Directive 2014/95/EU of the European parliament and of the Council has entered into force, this Directive amended the former Directive 2013/34/EU. According to the lawgivers disclosure of non-financial information is vital for transition towards a sustainable global economy that combines long-term profitability with social justice and environmental protection.

According to the Directive commercial undertakings and public interest entities must disclose non-financial information, if they exceed the average number of employees of 500 at the balance sheet date (EP, 2014).

Small and medium undertakings do not have the information duty. Theese undertakings most comon disclose non-financial information about community involvement and development area. Small and medium undertakings are closer to these issues than large one (Krasodomska and Gadowska, 2020). According to Zárybnická Žárová (2018) more than half of medium undertakings in the Czech 
republic disclose non-financial information, even though the Directive is not applied to them. The audit requirements has a positive effect on non-financial reporting of small undertakings.

Gazzola and col. (2020) made a research of non-financial reporting of public interest entities. During research, a positive trend in non-financial reporting was recorded, the public interest entities increases the availability of non-financial information on its website (the number of needed „clicks“ reduced), also increases the number of published areas.

In other reasearch on non-financial reporting of public interest entities, Coşofret a kol. (2020) dealt with Romanian companies that are listed on the Stock Exchange in Bucharest. Most selected companies disclose environmental information and employee issues. On the contrary, only half of the company sample disclose information on anti-corruption issues or human rights.

Before entering the Directive 2014/95/EU into force, reporting of non-financial information had a slightly growing trend, moreover, the disclosure of non-financial information was the most common for banks (Lament, 2017). According to another research, before entering the Directive into force larger and more leveraged financial institutions were more likely to extensively disclose their non-financial information (Andrikopoulos a kol., 2014). According to Andrikopulos a col. (2014), the main cause is greater visibility and greater need of confidence by shareholders of these institutions.

Before entering the Directive into force, the European Union has not been uniform in the non-financial reporting issue. Some countries such as France, UK, Sweden, Denmark, Spain and Finland had similar regulations already implemented at national level (Caputo a kol, 2019). In general, we can say that the western Europe is more advanced in non-financial reporting. It is appropriate to mention that the Polish Government was against the implementation of the Directive and wanted to leave this issue as a completely voluntary (Krasodomska a Godowska, 2020). Within the Czech Republic this activity is also not very popular and was considered as „inefficient administrative work“ (Mikulášková a kol., 2019).

Based on some research, non-financial disclosure could be profitable for some undertakings. Lenders, for the purpose of covering their own risks, require a higher yield from borrowers with worse levels of social responsibility (Goss a Roberts, 2011). Thus, bank directors are interested in this kind of information and take into account while creating bank contracts, audit certified information then increase their credibility in the mind of bank directors (Quick a Inwinkl, 2020).

Especially shareholders, but also society generally produce considerable pressure on undertakings to commit themselves to social responsibility and from nonfinancial reporting do an integral part of its annual reports (Khalil a O'Sullivan, 2017). However, this pressure often leads to so called ,greenwashing“, which means that companies invest more in presenting their own environmental measures than in the implementation of these measures (Pimonenko a kol., 2020). According to some studies, ,greenwashing“ did not avoid banks (Khan a kol., 2020; Khalil a O'Sullivan, 2017). The subject of research more often becomes the quality of disclosed information then their quantity. P. Kahn and col. (2020) assessed the quality of non- 
financial information as well as the quality of financial information, so based on their relevance and reliability.

\section{Methodology}

With regard to the main objective of the paper, ie the evaluation of the impact of the implementation of Directive 2014/95 / EU into the Czech Accounting Act in relation to the quantity and quality of reported non-financial information at financial institutions (banks), data from 2016 and 2019 were selected for comparison purposes. The year 2016 was chosen as the period before the implementation of the Directive and the year 2019 represents the most recent published non-financial information by banks already after the implementation of the Directive. Identified key indicators of non-financial reporting, which have been subsequently monitored their level of reporting banks surveyed in five basic areas, ie. environment, social issues, employees, respect for human rights and the fight against corruption and bribery. The starting point was the content analysis of banks' annual reports. The collected data were analyzed in terms of frequency of occurrence of selected criteria on which an arithmetic average for the reference area. A total of 48 banks were analyzed, which were then divided into three basic groups. These are banks with an obligation to disclose non-financial information, banks that are defined as large entities under the Accounting Act, and a group of other banks. After identifying the defined areas and content analysis of annual reports was assessed by the quantity and quality of non-financial reporting for the monitored group of banks in the years. For the comparison of reporting non-financial information by banks in the Czech Republic, the results were compared with data for banks in other V4 countries, as well as Germany and France, which were obtained from the EUKI by 2020. The V4 countries were selected with regard to a similar historical development, when it comes to open economies. Germany was selected for examination as a major export partner of the V4 and France, given that it was one of the first countries to introduce mandatory non-financial reporting at national level.

\section{Results}

Based on the directive, banks have an obligation to disclose information about the environment, social issues, care for employees, human rights and the fight against corruption. The data in Table 1 represent data for 2016, when the EU Directive on the Disclosure of Non-Financial Information has not yet entered into force, and for 2019, which are intended to represent the latest data and the situation in the field of corporate social responsibility. 
Table 1 The rate of non-financial information reporting entities

\begin{tabular}{|l|c|c|c|c|c|c|}
\hline \multirow{2}{*}{ Factors } & \multicolumn{2}{|c|}{ Group of banks 1 } & \multicolumn{2}{c|}{ Group of banks 2 } & \multicolumn{2}{c|}{ Group of banks 3 } \\
\cline { 2 - 7 } & $\mathbf{2 0 1 6}$ & $\mathbf{2 0 1 9}$ & $\mathbf{2 0 1 6}$ & $\mathbf{2 0 1 9}$ & $\mathbf{2 0 1 6}$ & $\mathbf{2 0 1 9}$ \\
\hline The environment & $35,71 \%$ & $51,79 \%$ & $11,36 \%$ & $38,64 \%$ & $6,25 \%$ & $10,00 \%$ \\
\hline Social Issues & $44,64 \%$ & $57,14 \%$ & $22,73 \%$ & $31,82 \%$ & $10,00 \%$ & $10,00 \%$ \\
\hline Empolyees & $52,38 \%$ & $66,67 \%$ & $24,24 \%$ & $33,33 \%$ & $15,00 \%$ & $20,00 \%$ \\
\hline $\begin{array}{l}\text { Respect of human } \\
\text { rihts }\end{array}$ & $40,48 \%$ & $54,76 \%$ & $3,03 \%$ & $9,09 \%$ & $6,67 \%$ & $8,33 \%$ \\
\hline $\begin{array}{l}\text { Fight against } \\
\text { corruption and } \\
\text { bribery }\end{array}$ & $42,86 \%$ & $67,86 \%$ & $4,55 \%$ & $15,91 \%$ & $5,00 \%$ & $6,25 \%$ \\
\hline
\end{tabular}

Group 1: Financial institutions with the obligation to publish financial information.

Group 2: Large financial institutions

Group 3: Other financial institutions

Only the group of banks 1 is obliged to disclose non-financial information. However, we can notice that there was an increase in reporting also for groups of banks 2 and 3, which do not have this obligation. This increase can be attributed not only to the introduction of the directive but also to the expanding trend of corporate social responsibility in the world.

Environmental information is reported by at least a group of banks 1 compared to other information examined and other non-financial reporting areas examined. In contrast, the banks without the obligation to make one of the most reported areas, even in group 2 banks saw the highest increase of all groups, it was an increase of almost 28 per cent points. There was a large increase in group 1 of banks, this increase was not as significant as in group 2. In the Social area, there was an increase only in the group of banks 1 and 2, by about 10 percentage points. There was no increase in the percentage of reporting for other financial institutions. In the area of employee care, there was an increase in reporting for all monitored groups of banks. The largest increase in reporting occurred in the group of banks 1 , by almost 15 percentage points. Non-financial information also includes reporting on Respect for human rights. This area is most frequently reported for Group 1 , where almost half of the entities in the Bank 1 group reported it before the entry into force of this Directive. This group also saw the largest increase. In our opinion, the area of corruption, bribery and money laundering is one of the most important areas for banking institutions. It was also not surprising to find that this group of banks 1 is the most frequently reported. Within 3 years, there 
was an increase in reported by 25 percentage points. Conversely, for banks without an obligation to report non-financial information, this area is one of the least published.

Table 2 compares the reporting of non-financial information in the Czech Republic with the reporting in other V4 countries and in France and Germany. The V4 countries were chosen because of a similar historical context and the same date of accession to the EU. Germany was chosen as the most important economic partner of the Czech Republic due to the significant share of foreign trade in GDP. France was the first EU country to introduce the obligation to report non-financial information.

Table 2 Comparison with selected EU countries

\begin{tabular}{|c|c|c|c|c|}
\hline States & $\begin{array}{c}\text { The } \\
\text { environment }\end{array}$ & Empolyees & $\begin{array}{c}\text { Respect of } \\
\text { human rights }\end{array}$ & $\begin{array}{c}\text { Fight against } \\
\text { corruption and } \\
\text { bribery }\end{array}$ \\
\hline The Czech republic & $26,67 \%$ & $100,00 \%$ & $40,00 \%$ & $90,00 \%$ \\
\hline Hungary & $8,33 \%$ & $50,00 \%$ & $50,00 \%$ & $75,00 \%$ \\
\hline Poland & $16,67 \%$ & $100,00 \%$ & $50,00 \%$ & $75,00 \%$ \\
\hline Slovakai & $27,80 \%$ & $50,00 \%$ & $33,30 \%$ & $58,35 \%$ \\
\hline Avegare of V4 & $19,87 \%$ & $75,00 \%$ & $43,33 \%$ & $74,59 \%$ \\
\hline Germany & $50,00 \%$ & $91,70 \%$ & $75,00 \%$ & $68,30 \%$ \\
\hline France & $57,80 \%$ & $100,00 \%$ & $80,00 \%$ & $80,00 \%$ \\
\hline
\end{tabular}

It is obvious that in most criteria the Czech Republic exceeds the average of the V4 countries, even in the area of the fight against corruption it even exceeds Western Europe. In the area of employee care, all banks in the Czech Republic and Poland report this information similarly, which is the same result as in France, and even more so than in Germany.

On the contrary, the Czech Republic shows worse results in comparison with Western Europe in the areas of human rights and the environment. These areas are comparable in reporting to other V4 countries. The area of human rights is the only area where we lag behind not only Western Europe, but also the average of the V4 countries. 


\section{Conclusion}

The research shows that after implementation, there was an increase in reporting in addition to the group of banks with the obligation to report non-financial information arising from the EU directive, also for banks that do not have this obligation. The increase in reporting at banks with obligations was therefore caused not only by the implementation of the directive into Czech accounting legislation, but also by the expanding trend of social responsibility. The second part of the research shows that the Czech Republic reports non-financial information to a greater extent compared to other V4 countries. On the contrary, the Czech Republic lags behind in comparison with Germany and France. The growing rate of reporting non-financial information in the Czech Republic by banks may therefore also be inspired by banks operating in Western European countries.

In addition to the annual reports, entities required to disclose non-financial information usually had separate sustainability reports for 2019 , which focused only on the bank's non-financial information and where most of the criteria we examined were mostly described. It should be noted that the amount and detail of the information provided varied from bank to bank. Some banks (in most cases those with an obligation to disclose non-financial information) had prepared very detailed reports with non-financial data supplemented by graphs, tables and other statistical data, and other banks published non-financial information to a very limited extent.

In the future, it can be assumed that the rate of reporting of non-financial information by banks will continue to increase. The reason is the fact that banks in the Czech Republic have committed themselves to gradually reduce their carbon footprint. They are making an increasing effort to report a certain part of so-called green assets in their assets. Specifically, these are loans provided to companies that approach the environment, climate change, etc. Banks are realizing that they need to take a comprehensive approach to these areas. Therefore, as a result, they will reflect in the price of loans the access of clients to these areas within their business. And they can use a simple tool to measure the impact of these measures, which is the level of interest.

\section{References}

1. Andrikopoulos A., Samitas A. a Bekiaris M. (2014), Corporate social responsibility reporting in financial institutions: Evidence from Euronext. Research in International Business and Finance [online]. 32, 27-35 [cit. 2021-03-17]. Dostupné z: https://www.sciencedirect.com/science/article/abs/pii/S0275531914000142

2. Bedenik N., Barišić P. (2019), Nonfinancial Reporting: Theoretical and Empirical Evidence. Sarfraz M., Adbullah M., Rauf A. a Gulam Meran Shah S. Sustainable Management Practices [online]. London: IntechOpen, s. 93-114 [cit. 2021-03-14]. ISBN 978-17-8985-1540. Dostupné $\quad \mathrm{z}: \quad \mathrm{https}$ //www.worldcat.org/title/sustainable-managementpractices/oclc/1131031823

3. Caputo F., Leopizzi R., Pizzi S. a Milone V. (2020), The Non-Financial Reporting Harmonization in Europe: Evolutionary Pathways Related to the Transposition of the 
Directive 95/2014/EU within the Italian Context. Sustainability [online]. 12(1), 1-13 [cit. 2021-03-20]. Dostupné z: https://www.mdpi.com/2071-1050/12/1/92

4. Coșofreț B., Mârț R. a Manea M. (2020), An overview of the non-financial reporting practices of the romanian public-interest entities listed on Buchurest stoch exchange. Revista Economica [online]. 72(1), 57-64 [cit. 2021-03-14]. Dostupné z: http://web.a.ebscohost.com/ehost/detail/detail?vid=0\&sid=45cbd56d-6fc6-4141-a5ab83d4e3921d88\%40sdc-vsessmgr02\&bdata=Jmxhbmc9Y3Mmc210ZT11aG9zdC1 saXZl\#AN=145251073\&db=bsu

5. European Central Bank (2021), Climate change and central banking [online]. 2021 [cit. 202103-15]. Dostupné https://www.ecb.europa.eu/press/key/date/2021/html/ecb.sp210125 f87e826ca5.en.html

6. Gazzola P., Pezzetti R., Amelio S. a Grechi D. (2020), Non-Financial Information Disclosure in Italian Public Interest Companies: A Sustainability Reporting Perspective. Sustainability [online]. 2020, 12(15) [cit. 2021-03-14]. Dostupné z: https://www.mdpi.com/2071-1050/12/15/6063

7. Goss A., Roberts G. (2011), The impact of corporate social responsibility on the cost of bank loans. Journal of Banking \& Finance [online]. 7(35), 1794-1810 [cit. 2021-03-20]. Dostupné z: https://www.sciencedirect.com/science/article/pii/S0378426610004498

8. Khalil S., O'Sullivan P. (2017), Corporate social responsibility: Internet social and environmental reporting by banks. Meditari Accountancy Research [online]. 25(3), 415-443 [cit. 2021-03-21]. Dostupné z: doi:10.1108/MEDAR-10-2016-0082

9. Khan, H., Bosa S., Mollik A. a Harun H. (2020), "Green washing” or "authentic effort”? An empirical investigation of the quality of sustainability reporting by banks. Acounting, Auditing \& Accountability Journal [online]. 34(2), 338-369 [cit. 2021-03-21]. Dostupné z: https://doi.org/101108/AAAJ-01-2018-3330

10. Krasodomska J., Godawska J. (2020), CSR in Non-Large Public Interest Entities: Corporate Talk vs. Actions. Sustainability [online]. 12(21) [cit. 2021-03-14]. Dostupné z: https://www.mdpi.com/2071-1050/12/21/9075

11. Lament M. (2017), Quality of non-financial information reported by financial institutions.: The exampel of Poland and Greece. Central European Review of Economics \& Finance [online]. 22(6), 5-16 [cit. 2021-03-15]. Dostupné z: doi:10.24136/ceref.2017.023

12. Mikulášková B., Batelková K., Malinková I. (2020), Povinnost vykazování nefinančních informaci $v$ České republice. In: Helísek M. Prezentace výsledků ekonomického a finančního výzkumu doktorandů. Praha: Vysoká škola finanční a správní, 2020, s. 71-80. ISBN 978-807408-218-4.

13. Pimonenko T., Bilan Y., Horák J., Starchenko L., Gajda W. (2020), Green Brand of Companies and Greenwashing under Sustainable Development Goals. Sustainability [online]. 12(4), 1-15 [cit. 2021-03-21]. Dostupné z: https://doi.org/10.3390/su12041679

14. Směrnice Evropského parlamentu a rady 2014/95/EU ze dne 22. řijna 2014, kterou se mění směrnice 2013/34/EU, pokud jde o uváděni nefinanční informací týkajících se rozmanitosti některými velkými podniky a skupinami. In: . Štrasburk, 2014, ročník 2014, číslo 95. Dostupné také z: https://eur-lex.europa.eu/legal-content/CS/TXT/?uri=CELEX\%3A32014L0095

15. Quick R., Inwilk P., (2020), Assurance on CSR reports: impact on the credibility perceptions of non-financial information by bank directors. Meditari Accountancy Research [online]. 28(5), 833-862 [cit. 2021-03-20]. Dostupné z: doi:10.1108/MEDAR-102019-0597

16. Zárybnická Žárová M. (2018), Zveřejňují střední a malé podniky v ČR nefinančni informace? Český finanční a účetní časopis [online]. 2018(4), 71-83 [cit. 2021-03-20]. Dostupné z: doi:10.18267/j.cfuc.523 
17. EUKI [online]. 2020 [cit. 2021-5-15]. Dostupné z: https://www.euki.de/ 